\title{
Forced labor practices of Indonesian migrant fishing vessels crew on Taiwan- Flagged Ships? A need for cognitive framework transformation
}

\author{
Fitri Soulina
}

Department of Sociology, Faculty of Social and Political Sciences, University of Indonesia, Indonesia

Email: fitrisoulina@ui.ac.id

Nadia Yovani

Department of Sociology, Faculty of Social and Political Sciences, Universitas Indonesia Email:nadia@ui.ac.id

\begin{abstract}
The foreign labor market delivers Indonesian workers with low qualifications for work in the informal fisheries sector as a fishing vessel crew (AKP). On the one hand, the use of Indonesian workers assists in increasing the absorption of domestic labor. Still, in real conditions, the workers are confronted with violations practices of labor rights. More than that, in the homestead, migrants' fishing vessel crew experience the repudiation of labor rights and human rights. Based on previous studies mapping, the phenomenon 'labor exploitation' is associated with functional dimensions of policy and regulation and its relation to rational action in the economic context. Those case studies of Taiwanese flagship's fishing vessel crew have not yet caught on to the complexity of continuous practice in Indonesian migrants from recruiting procedures to entirely adhering to the causes of migrants' precariousness. Using institutional analysis, the findings show the dynamics between institutions and actors in
\end{abstract}


the labor market, ignoring important micro aspects to transpose to eliminate occupational practices. Neglect of the social-economic context's cognitive element builds a considerable gap between existing beleid and the resulting transformation.

Keywords: Fishing Vessel Crew, Forced Labour, Institutional Framework, Migrant Worker

\section{Introduction}

The foreign labor market is an alternative for Indonesian workers who are faced with the reality of the limited absorption of labor in the country. BPS data (2019) shows that the Indonesian workforce is dominated by a large proportion of the population with primary and junior high school education. Productive age population with the latest education completed at the elementary school level is $23.6 \%$ and junior high school is $22.8 \%$. This condition places Indonesian migrant workers as fulfilling the needs of workers in the business sector "Agriculture, Animal Husbandry, Forestry, Hunting and Fisheries" $(\mathrm{PPKPP})^{1}$. The urgency of Indonesian migrant workers for the informal sector is relatively high for countries in Asia, including: Malaysia, Taiwan, Hong Kong, Singapore, Saudi Arabia and South Korea.

Table 1: Number of Indonesian Migrants FVC in Taiwan in 2014-2019

\begin{tabular}{|l|c|c|c|c|c|c|} 
& 2014 & 2015 & 2016 & 2017 & 2018 & 2019 \\
\hline $\begin{array}{l}\text { Number of } \\
\text { Migrants FVC } \\
\text { on Taiwan } \\
\text { Ships }\end{array}$ & $8.765^{\mathrm{a}}$ & $7.748^{\mathrm{a}}$ & $\begin{array}{r}6.989^{\mathrm{a}} \\
6.860^{\mathrm{b}}\end{array}$ & $8.499^{\mathrm{a}}$ & $9.081^{\mathrm{a}}$ & $9.351^{\mathrm{a}}$ \\
\hline $\begin{array}{l}\text { Number of } \\
\text { LG }\end{array}$ & & & & & & \\
\hline $\begin{array}{l}\text { FVC } \\
\text { FVigrants }\end{array}$ & - & - & - & - & $12.748^{\mathrm{d}}$ & $13.598^{\mathrm{d}}$ \\
\hline
\end{tabular}

Source: a Ministry of Labor R.O.C Specific in the fisheries sector

b Diolah dari Workforce Development Agency, MOL 2016 Specific in the fisheries sector c DPN SBMI, 2019 Specific in the fisheries sector

d Council of Agriculture R.O.C

1 Data refers to the Indonesian Business Field Group (KLUI) for all countries where migrant workers are placed. The PPKPP sector ranks third after the 'Community Services' business sector and the 'Manufacturing Industry' business sector (PPID BNP2TKI, 2020) 
In line with the Indonesian migrant workers' labor statistics that are experiencing changing trends ${ }^{2}$, the real conditions in the field show that the reputation of Taiwan's fisheries sector has recently been damaged due to distant water fishing vessels. Taiwan is associated with illegal, unreported and unregulated (IUU) fishing activities. Based on data from the Global Initiative Against Transnational Organized Crime in 2019, Taiwan's IUU index is 3.34 (out of 5) which makes Taiwan the second highest IUU country in the world where as many as 20,000 migrant workers, mostly from Indonesia and the Philippines (Greenpeace, 2020) . Migrant FVCs on Taiwan-flagged ships are in a vulnerable position to experience various forms of violations of labor rights and human rights. The argument for the violation is based on the term "forced labor" used by the International Labor Organization (ILO) after the ratification of forced labor Convention No. 29 in 1930. There are eleven actions that are used as indicators in terms of forced labor.

Other countries which are the main suppliers of migrant workers are Cambodia with the most placement in Thailand and the Republic of Korea ${ }^{3}$. Generally, workers become migrants in fisheries, agriculture, manufacturing and service sectors ${ }^{4}$. Only a small proportion of workers go through administrative processes in recruitment procedures, with 53 percent of migrant workers dependent on brokers (ILO and IOM, 2017). There are similarities in the problems faced by Cambodian migrants with Indonesian migrant FVC, namely the recruitment process through brokers in villages. Brokers are considered by the community as the key party who will provide information about the jobs available in the port area to the process of placing workers on Thai ships.

2 Data from the National Agency for the Placement and Protection of Indonesian Migrant Workers (BNP2TKI) shows that the number of Indonesian Workers is currently experiencing a changing trend. In 2018 as many as 90,671 PMI people were stationed in Malaysia, the number decreased in 2019 to 79,663 people. This decrease is in line with the increase in the number of PMIs for Taiwan placement, which in 2018 amounted to 72,373 to 79,574 PMIs in 2019. Specifically in the fisheries sector, Indonesian migrant workers rank first as workers on foreign ships who are the top three tuna traders at the global level, namely vessels with flags Taiwan.

3 Started in 2010

4 Of the 8.8 million workers in Cambodia, the number of migrant workers who are bound by the $\mathrm{MoU}$ is 311,290; Migrant workers completing nationality verification amounted to 64,273 ; Migrant workers register under one roof of 304,660 Department of Employment, Ministry of Labor, Thailand (August, 2019) 
Demographically, Cambodian migrant workers are dominated by young and low skilled emigrants who have completed their education at the primary school level by 53\% (MOP, 2012). In 2014, policies on labor migration centered on three strategic targets, namely strengthening the role of the Ministry of Labor and Vocational Training (MOLVT) structure of the national committee as a form of resistance to the practice of Human Trafficking; and strengthening immigration law enforcement.

On the one hand, the presence of migrant workers from neighboring countries is a threat to Thailand's stability and security (Chalamwong, 2004: $359,361)$. The registration policy for undocumented migrant workers is an effort taken by Thailand in a formalized system of all procedures that workers go through from the start of recruitment to returning to their home country (Derks, 2010).

Exploitative conditions in the fisheries global value chain (GVC) are not only experienced by Migrant FVCs on Taiwan-flagged vessels, but also among workers on ships with South Korean flags sailing in New Zealand waters. However, in contrast to the structural measures taken by the Taiwanese government, New Zealand, through its Ministry of Manpower, made regulations that could cover this problem. Since 2012, the New Zealand Government has established a Ministerial Inquiry, where every ship with a foreign flag in New Zaeland waters must be reflagged as a New Zealand flag ship. In 2016 the ship operated under New Zealand Employment law. In addition, migrant fishing vessel crews are also assigned to three different contracts on behalf of Indonesia, New Zealand and South Korea.

\section{Literature Review}

Broadly speaking, various studies conducted on the topic of violence against Migrant FVCs refer to three different focuses, namely: (1) problems that arise due to the limitations of existing laws and regulations; (2) problems that were initiated by the existence of socio-economic disparities in society, and (3) actions that were born as a consequence of the strength of the Global Value Chain. These three conditions are manned by two different dominant actors, namely the government and the economic actor / private sector of the international labor market. In the first factor, the problem develops when the regulations that become the reference for the protection of migrant workers

5 MOLVT is the main organization in handling migration https://www.oecd-ilibrary.org/ 
and / or in particular Migrant FVCs fail to explain the clear division of legal jurisdictions between ministries, agencies and other government agencies at the provincial level. The second factor brings the situation to. In the third factor, the problem is rooted in the demand for fish which causes high demand for low-cost labor. This is based on the desire to meet the export needs of labor-user countries.

\section{a. Forced Labor in a Sociological Perspective}

Forced labor is a term used by the International Labor Organization (ILO) to define ideal labor practices and abusive labor practices. The goal is to intervene strategically on workers. In academic studies, defining forced labor is a term that cannot be separated perfectly from other concepts such as modern slavery, servitude, and smuggling (Patterson, 2018).

Labor crimes by Coretta Phillips (2019) place workers in general in an economic framework in a precarious position or have no knowledge of workers' legal standards (Anderson and Rogaly, 2005). The practice of forced labor is culturally rooted and its contextual forms vary including: debt bondage, forced labor, violent labor, and the accidental insertion of individuals into a job ${ }^{6}$. This right is used to complete control over slaves using threats or violence, and the lack of wages than should be paid for an economic gain. At present, modern slave is defined as a condition that depends on law; facilitated by an abundance of potential low-paying slaves; high profit; relationships of a short nature; ease of changing workers; There is often a perception bias regarding the place of work and place of residence at the time of placement (Bales, 2004; cf. Bravo, 2007).

The main idea that was built regarding forced labor emphasized policy and political elements that focused on one institution, namely the workplace. The argument is based on the lack of flexibility in that the time allocated in the workplace contains high human capital costs. A large number of structural processes and organizational practices lead to economic, technological and family actions that are central to management and control over labor (Correta Philips, 2018). The emphasis on strong cultural and moral schemes is a combination of organizational practice in the workplace. Based on this, Philips builds broader conceptual ideas and political schemes that allow the formation of structures and cultures that must be changed in order to fade pressures and imbalances in labor practices.

6 Bales (2004) uses the term 'modern slavery' 


\section{b. Process of Implementing Legislation and Supervision by the Government}

Migrant worker migration schemes in Indonesia involve many stakeholders, especially in relation to labor migration policy and implementation, the welfare of migrant workers, law enforcement and offices in various missions of the Indonesian government abroad. The division of jurisdictions between government agencies as well as state institutions at the national and provincial levels has an impact on poor coordination between agencies and / or duplication of work (Ford, 2005).

In handling labor migration, the Indonesian government involves various ministerial roles. This involvement is intended for the implementation of labor migration, the welfare of migrant workers, law enforcement and offices in various Indonesian government missions abroad as resource centers for various labor migration issues. The division of authority between Ministries is based on Law no. 39/2004, which contains the mandate for cooperation between government agencies in emergency situations and the relationship between central, regional and local governments. However, this regulation fails to explain the division of jurisdiction between government agencies. This regulation does not provide much division of roles in the government at various levels. This has a major impact on the credibility and transparency of the system, particularly in relation to the training process before the departure of migrant workers; direction and directive and supervision mechanisms; so that it becomes room for abuse of the stages during the migration process (IOM, 2010).

Migration of workers in legal market conditions is exacerbated by weak supervision by the government. Finckenauer (2007, pg 68) uses the term "spectrum" of economic activity and / or legal business, where business and legality are fluctuating points in the "spectrum". these changes depend on new laws and / or regulations (pg 68-69). Changes in the legality of economic activities cannot always change the behavior of actors in the scheme, changes that occur can only be in the form of a condition that was initially legal to illegal or vice versa. This 'spectrum' supports fisheries business actors, as normal and rational actors with profit-oriented, entering into the context of illegal actions that are driven by the law of supply and demand so that what happens is a crime in the fisheries business (Kleemans, 2012, p. 616). This practice in this study is seen as an attempt by actors (entrepreneurs) to develop, maintain, control and expand illegal markets (Finckenauer, 2007). 


\section{c. Global Value Chain and Economic Action}

Continuity of forced labor on migrant FVC fisheries is based on high demand for fish which causes high demand for low-cost labor so that potential customers for goods and services can still be served (Lyman and Potter, 2007). Conditions in the legal market are exacerbated by the weakness of government oversight. The practice of violence and extortion in this study is seen as an attempt by actors (entrepreneurs) to develop, maintain, control and expand illegal markets (Finckenauer, 2007). Fisheries crime perpetrators are considered normal and rational actors with a profit orientation and enter the context of illegal acts driven by the law of supply and demand (Kleemans, 2012, p. 616).

Globalization, market privatization, and economic growth increase inequality within and between countries and at the same time massively increase communication channels between individuals. In the end, the process enables various individuals to obtain information on job opportunities and increases the desire to migrate. Globalization with all the conveniences of transportation and communication facilitates the performance of human trafficking, especially international criminal organizations. He calls this situation "globalization, migration and trafficking of the nexus" (Doomernik, 2006).

Studies with an econometric approach ${ }^{7}$ on the anomalous analysis of the placement of migrant workers on Taiwan-flagged ships yielded positive findings. The placement of Migrant FVCs is based on internal / domestic factors and external factors as well as consideration of rational choices that are considered to be beneficial to the state and society. The author views that the Government of Indonesia prioritizes placing FVC for migrants on Taiwanese ships based on common interests and on the basis of the principle of sustainability in political, economic and social aspects. Considering that until now Indonesia and Taiwan do not have diplomatic relations, the policy of placing Indonesia's FVC in Taiwan is expected to improve non-diplomatic economic and political relations due to the 'One China Policy' system adopted by Indonesia. The socioeconomic impact that has been felt is the reduction in the unemployment rate in Indonesia. The long-term impact is the growth of the level of welfare, defense and security. It is assumed that one migrant worker can meet the economic needs of three family members in Indonesia. The implementation of a moratorium that was carried out by the Indonesian government for Taiwanese ships will have

7 Viewing humans as homo economicus where economic factors are the main factor in everyday life. 
an impact on the welfare of domestic workers. The prevailing assumption is that one migrant worker supports 3 other people in the family, so that four people will experience welfare problems if the head of the family does not work. On the other hand, at the national level the moratorium will reduce the absorption of domestic labor. If the economic aspects of a country are disturbed, other aspects will also experience problems, including those related to social resilience and stability of the country. In the end, the policy of placing AKPs on Taiwanflagged ships was still carried out in the framework of fulfilling public welfare and fostering good non-diplomatic relations with Taiwan (Damarsidi, 2017).

\section{d. Conceptual Framework: 'Market Field'}

The use of institutional analysis in this research aims to amplify the understanding of the causes for the continuity of forced labor practices in Indonesian migrant workers which are seen not only as organized illegal acts carried out by economic organizations, but the involvement of other formal social structures in forced labor. The application of institutional analysis is an adaptation of Beckert's (2010) idea of "dynamics in the market" as a sociological approach to economic action which is the result of the dynamics of three types of social structures simultaneously. The three social structures, namely: network structures, institutions, and cognitive frameworks, act as social forces that have relevance to economic outcomes. He admitted that social power is contradictory and exists in one 'social arena' (field) ${ }^{8}$ where the interrelationships of the three establish reciprocal mechanisms so that actors in it can make structural changes.

Good reproduction of the three social forces in question will be able to eliminate changes in social situations. However, this is not the case if there is a malfunction of one of these social forces. This is based on the heterogeneity of actors in the forced labor scheme which includes actors with economic orientation; actors who play a role in creating social stability; and actors who throughout the practice of forced labor have only become objects of the actions of other actors and only occupy powerless positions in market fields.

8 The concept of the field used by Beckert refers to the concept developed by Fligstein (2001). Field is understood as a 'local social order' or 'social arena' where actors collect and frame their actions vis-a-vis other actors 
Forced labor practices of Indonesian migrant fishing vessels crew ... (Fitri Soulina, Nadia Yovani)

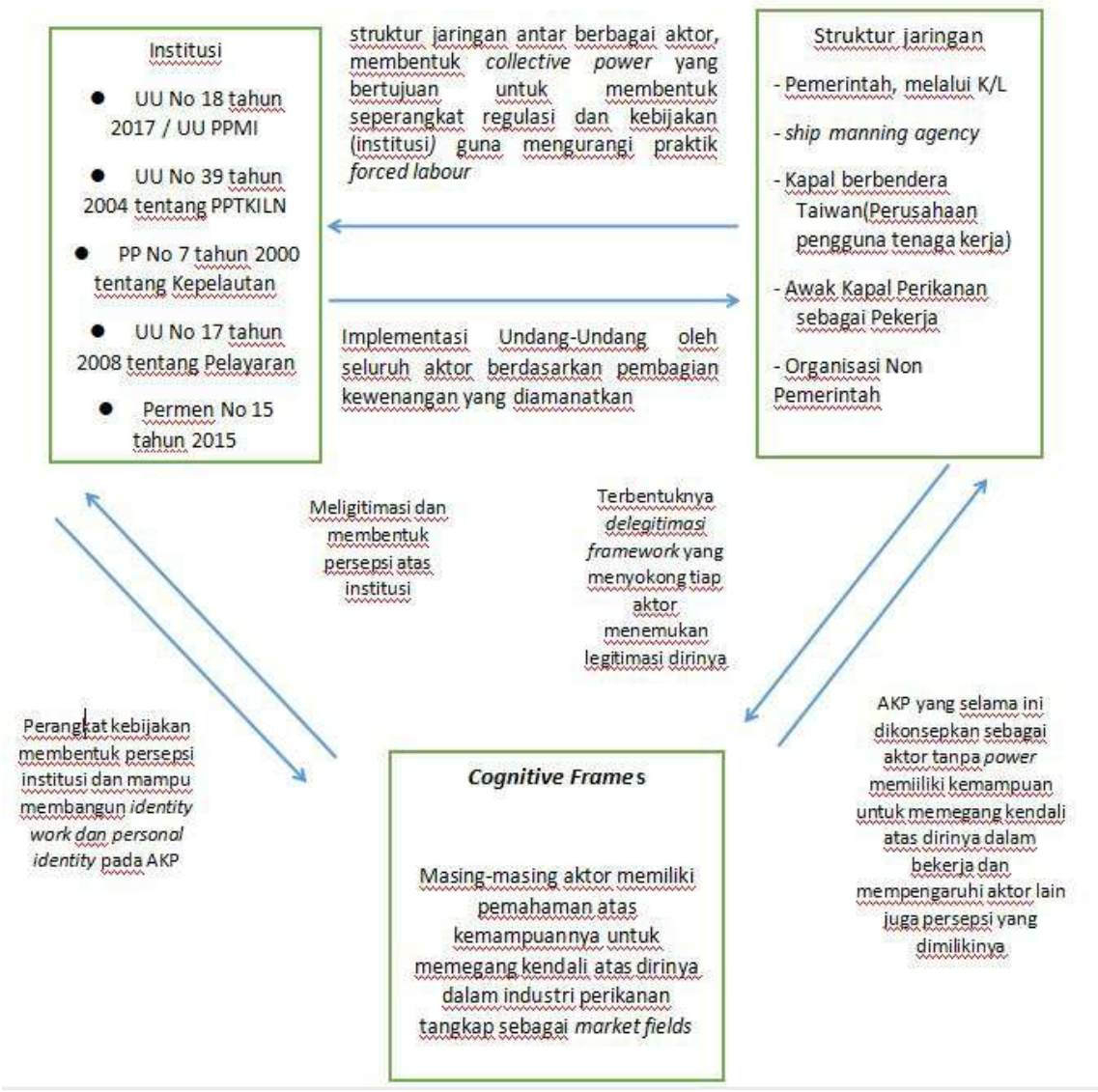

Figure 1: Conceptual Framework: 'Market Field'

Source: Processed by researchers

\section{Methods}

This study uses a qualitative approach with the type of case study research that seeks to reveal specific things contained in individuals, groups, communities or organizations in everyday life in a comprehensive, detailed, deep and scientifically accountable manner (Miles and Huberman, 1994). . Researchers explore phenomena that are limited by aspects of time (time series) and activities (processes, programs, events, institutions, or social communities) and collect detailed data obtained through various data collection methods (Cresswell, 2002). This process is carried out to make a comprehensive description of the 
forced labor practice of Migrant FVC as workers and to analyze the institutional framework in labor activities that perpetuates the forced labor practice of the migrant FVC in a comprehensive manner.

Data collection techniques in this study were carried out through indepth interviews in order to obtain an overview of the domestic institutional framework; dynamics of social interaction between stakeholder actors in labor practices involving economic actors (private), government and non-government organizations who are stakeholders in the effort to handle forced labor practices of Indonesian Migrant Workers Association; also confirm the data that has been collected; get information. As a complement to the data in the study, the researchers conducted a documentary study to collect data on the description of forced labor practices experienced by the Migrant FVC, the changes in the number of migrant workers on Taiwan-flagged ships from year to year.

The institutional analysis method in this research is used as a method of identifying the development of the institutional framework. The steps taken are (1) evaluation of the results of the diagnoses that have been carried out; (2) make a trend analysis to trace historical developments; (3) carry out development tracking in institutions; (4) conducting institutional evaluations that have implications for ongoing performance; (5) assessing the adequacy and suitability of the existing institutions; and (6) identify possible institutional changes. In addition, descriptive-qualitative data analysis was carried out in order to obtain a description of the forced labor practices experienced by the Migrant FVC. Meanwhile, the validation in this study was obtained through the intersubject node which was then confirmed by a triangulation mechanism.

\section{Results And Discussion}

\section{'Market Field, Elements in the Migrant Fisheries Migrant FVC Recruitment and Placement Scheme}

\section{A. Elemen Institusi dalam Skema Rekrutmen dan Penempatan}

During the approximately two decades of Indonesia's journey to resolve the upstream to downstream problems of migrant workers, there are five laws and regulations that can be used as the center of observation. 
Table 2: Institutional relevance with the aspect of protection of Migrant FVC

\begin{tabular}{|c|c|}
\hline lations & $\begin{array}{l}\text { Relevance with the Aspects of Migrant Migrant FVC Protection in the } \\
\text { Recruitment and Placement scheme }\end{array}$ \\
\hline $\begin{array}{l}\text { Government Regulation } \\
\text { Number } 7 \text { of } 2000 \\
\text { concerning Maritime } \\
\text { Affairs }\end{array}$ & $\begin{array}{l}\text { Regulates the Sea Work Agreement (SWA). The placement of migrant } \\
\text { workers can be carried out directly by a seafaring worker placement } \\
\text { service company that has met the operational standards / requirements } \\
\text { of having a seafarer employment placement business license. In this case, } \\
\text { if the worker does not have a street vendor, then the worker will not get } \\
\text { interference from the government if one day he experiences a dispute } \\
\text { related to these points in the street vendor. } \\
\text { The role of the Ministry of Manpower in this PP is to set the lowest } \\
\text { minimum wage for Migrant FVCs. } \\
\text { In this PP, the aspect of protection for migrant workers from the } \\
\text { recruitment to placement phase is very low. Regulations generally only } \\
\text { accommodate administrative interests. }\end{array}$ \\
\hline $\begin{array}{l}\text { Law } 39 \text { of } 2004 \\
\text { concerning the } \\
\text { Placement and } \\
\text { Protection of } \\
\text { Indonesian Workers } \\
\text { Abroad }\end{array}$ & $\begin{array}{l}\text { Provide a large portion for private companies (PPTKIS) to carry out } \\
\text { recruitment and placement procedures, not directly by government } \\
\text { agencies. Although the PPTKIS in its operational procedures need to } \\
\text { get permission from the Ministry of Manpower. The protection function } \\
\text { for migrant workers for individual users is borne by the Private TKI } \\
\text { Placement Implementer (PPTKIS). } \\
\text { There are only eight articles that regulate the protection of workers, } \\
109 \text { other articles in the Act mostly only regulate the substance of the } \\
\text { placement of workers by non-government agencies, namely private ship } \\
\text { manning agencies. }\end{array}$ \\
\hline
\end{tabular}




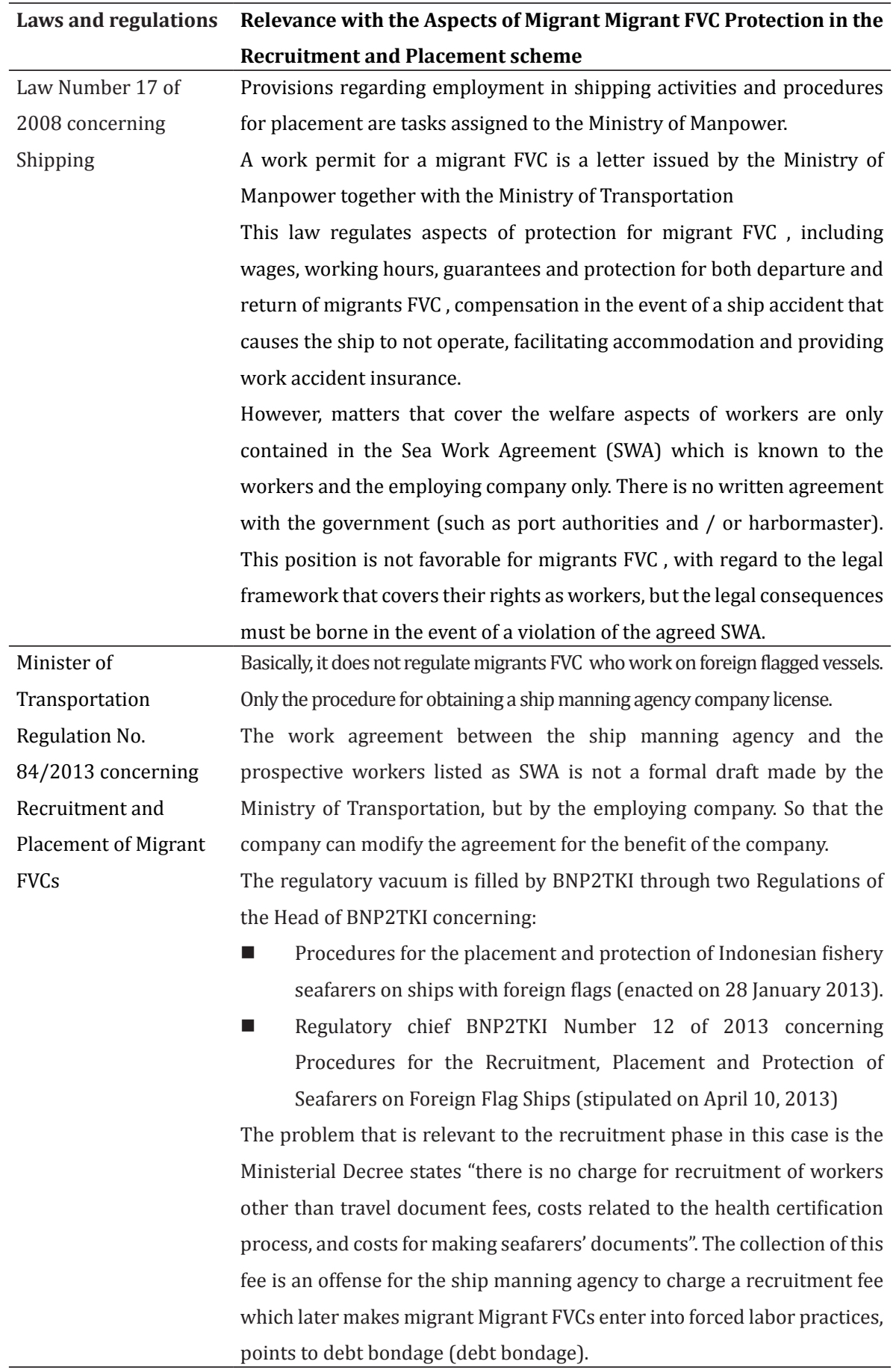




\begin{tabular}{ll}
\hline Laws and regulations & $\begin{array}{l}\text { Relevance with the Aspects of Migrant Migrant FVC Protection in the } \\
\text { Recruitment and Placement scheme }\end{array}$ \\
\hline Law number 18 of & $\begin{array}{l}\text { Starting to shift the general paradigm that develops in the community } \\
\text { re17 concerning }\end{array}$ \\
the Protection of & strong oriented to the business aspect with an orientation to increase \\
Indonesian Migrant & productivity, and contain elements of neglect of protection aspects. The \\
Workers (UU PPMI) & $\begin{array}{l}\text { application of sanctions and fines aimed at the employer and / or other } \\
\text { parties on board is stronger than the policies and regulations that have }\end{array}$ \\
& $\begin{array}{l}\text { been issued previously. } \\
\text { However, the PPMI Law does not contain derivative regulations for related } \\
\text { ministries and institutions to form a special agency that has special duties } \\
\text { and functions for the migrant worker sector. This regulation also does not } \\
\text { include any derivative regulations that accommodate the settlement of } \\
\text { industrial disputes between Migrant FVCs and ship management agencies. }\end{array}$
\end{tabular}

Source: Processed by researchers

In this study, the Ministry of Manpower is the main actor which is constitutionally written in Law number 18 of $2017^{\circ}$. Apart from the Ministry of Manpower, another actor, namely BNP2TKI with the role of regulating permits for sending migrant workers ${ }^{10}$. The network structure and power relations in these fields go through the agency process in an effort to reduce or eliminate foreced labor practices due to the movements of each of the existing social forces which are imperfect.

Even though there has been a change in perspective in the preparation of the statutory framework, the presence of force in the PPMI Law issued in 2017 has not succeeded in transforming society. In the report of the Indonesian Migrant Workers Union (SBMI, 2020), based on complaints from migrant fisheries Migrant FVCs from 2010 to 2020, the number actually increased in 2016 and 2019. Hariyanto, chairman of the SBMI said that the average increase was 55.3 percent annually, where in 2016 the number of reported cases was 491 cases and in 2019 as many as 640 cases. With regard to freedom of association, both in the country and in the country of placement, it does not

9 The law is used as a reference for this study in analyzing the role of actors and their implementation within the institutional framework.

10 This institution is the only institution that has the capacity to coordinate and has the authority to protect $G$ to $G$ with foreign countries and can also make direct contact with worker protection offices in overseas. 
have a significant impact on the Migrant FVC. Imam Syafi'I, chairman of the Indonesian Seafarers Movement (PPI) Adkumham, said that out of 1,154,997 seafarers officially registered ${ }^{11}$, there are only 8,000 more seafarers who are members of the PPI. . This number includes seafarers in the commercial sector as well as in the domestic and foreign fisheries sector. "... only a few, at least 5 percent, our members are from fisheries crew ...” (Syafi'I, 2020).

\section{B. Cognitive Framework}

In order to understand the ongoing labor migration as migrants FVC on foreign-flagged vessels, it is necessary to understand the socialeconomic landscape of the population in the territory of Indonesia which is the international "Kantung ABK" in Indonesia. Indonesia's "Kantung ABK Internasional" are in the Tegal, Batang and Pemalang areas. Data from the Indonesian Migrant Workers Union shows that every year no less than 2000 migrant FVC from Pemalang depart to work on fishing boats in Fiji, Korea, Taiwan, Singapore and Malaysia. The country with the most migrant workers from Indonesia is Taiwan, with the number reaching 12,991 worker in 2019, while in the Philippines the number is only 6,016 workers on fishing boats (SBMI, 2019). The number of Migrant FVCs in this city has increased every year, the DFW Field Manager stated that during the process of mentoring prospective migrant workers for the past 2 years, the motivation to become a Migrant FVC generally emerged after seeing the success of other residents returning to their homeland and building houses., owning the latest electronic devices, and other things that improve welfare. Needs that are economical in nature, experience support obtained through social interaction is facilitated by the flow of information, making the Migrant FVC recruitment process easier to carry out where the recruiting company or ship manning agency is easy to get information about the population with the characteristics required and the population as the party who needs work be sure to follow the recruiting flow (AM, April 2020).

11 Based on the official website data of the Directorate General of Sea Transportation, Ministry of Transportation as of February 2020 
Forced labor practices of Indonesian migrant fishing vessels crew ... (Fitri Soulina, Nadia Yovani)

Table 3: Placement of Indonesian Migrant Workers by Education Level $2018-2019$

\begin{tabular}{clcc}
\hline No & Level Of Education & 2018 & 2019 \\
\hline 1 & Postgraduate & 2 & 3 \\
\hline 2 & Bachelor & 95 & 130 \\
\hline 3 & Diploma & 253 & 223 \\
\hline 4 & Senior High School & 7.532 & 8.028 \\
\hline 5 & Junior High School & 8.146 & 9.089 \\
\hline 6 & Elementary School & 7.403 & 8.016 \\
\hline & Total & 23.431 & 25.489 \\
\hline
\end{tabular}

Source: PPID BNP2TKI, 2020

Working as a Migrant FVC is considered to be one of the most desirable jobs for people with the highest level of primary education. The demand for countries in Southeast Asia is quite high and the requirements put forward by the ship manning agency are easy, the salaries offered are high for this standard of education, moreover workers get help to fulfill the documents needed for the process of traveling abroad. Prospective workers generally already know that working as an Migrant FVC is a job with a relatively high risk of violence compared to other jobs carried out outside the marine area.

"FVC come from the lowest economic class in Indonesia. They did not get the opportunity to work with a salary of 450 USD while working in Indonesia. Even though they experience it (violence), they don't bother to work and even those who go home sailing when asked if they want to come back again or not, they want to be crew members again. Go home if the young ones buy a big motorbike, the iPhone is like that .. "(SR, Jakarta, April 8, 2020).

The character of the Indonesian workforce, which is dominated by workers with low qualifications, makes the principles of flexibility only carried out by certain actors in relation to its character as a profit-oriented organization. This qualification places workers in the informal sector, especially in this study, the third highest number of migrant workers are workers who are placed in dangerous sectors or in dirty, dangerous, difficult (3Ds) ${ }^{12}$ work environments.

12 This working environment condition was mentioned by the Coordinating Minister for Maritime Affairs in describing the work environment faced by migrants FVC. 
work faced by migrants FVC. The dominance of workers with junior high school education indicates that workers are less likely to be able to transfer from one company to another; switching to other industries or sectors; and or choose the location where you work. This condition shows that Indonesian workers are attached to their inability to take advantage of opportunities as entrepreneurs are free to make choices about existing opportunities (Tjandraningsih, 2004).

The real condition shows that Migrant FVCs in the recruitment and placement scheme are in a situation that is covered by various non-procedural / illegal aspects. Migrant FVC are placed economically, socially and or culturally in a position full of vulnerability. Each of the factors that cause vulnerability will lead workers to forced labor and exploitation practices. Although changes in policies and regulations have been carried out by the Indonesian government, the practice in the field illustrates different conditions. Based on monitoring of the slavery of Indonesian migrant workers carried out by the Indonesian Migrant Workers Union (SBMI), from 2010 to 2019, the trend of slavery tends to increase. The increase is an average of 55.3 percent each year. The highest increase in complaints occurred in 2016 with 491 cases and 2019 with 640 cases. The total number of complaints documented was 2,456 cases. In the details of cases monitored by SBMI, in general there are 3 groups most vulnerable to experiencing slavery in various forms, these groups include Domestic Workers (PRT) of 60.38 percent (1,483 cases); Fisheries Ship Crew (ABK) 10.46 percent (257 cases). During 2015-2020, 11 crew members died on board from 3 ships with foreign flags, namely China, Taiwan and Vanuatu. The number increased quite high in 2020 to reach 15 people from 11 Chinese ships and 2 Taiwan ships. This was explained further by Hari in the action title which took place in the Lobby of the Nusantara I Building of the DPR-RI Jakarta. Based on the narrative of Hariyanto, the general chairman of SBMI (2020) the number of crew members who died whose handling process was advocated for or received directly from the victim's family by SBMI only covered less than 1 percent of the real conditions in the field. Especially in the national media, the number of data not monitored by SBMI is more than that, reaching 28 cases for ships with Chinese and Taiwanese flags (Ester Meryana, 2020).

On a Taiwanese vessel operating as a Coastal Fishing Vessel, workers only fish on boats near Taiwan and / or around Japan. In addition, there are ships operating for the distance water fishing fleet to catch fish on high seas; Atlantic and Pacific oceans. Most of the Coastal Fishing Fleets carry out Government to Government recruitment between the Taiwanese government 
and the Indonesian Government through the BNP2TKI agency. However, of the hundreds of ship manning agencies operating in Indonesia, up to November 2017, only 72 ship manning agencies had Migrant FVC Recruitment and Placement Business Permits (SIUPPAK). This number is mostly commercial ship manning agency for the placement of cruise ships and / or cargo where the requirements for the workers are different. Workers on cargo ships do not need to have special skills and protection during work such as safety jackets as required for FVC. (Tempo Institute, 2017). On the other hand, FVCs originating from Indonesia are not workers who meet the qualifications to be able to register according to the recruitment requirements of BNP2TKI. So that it becomes an inaccurate understanding if you look at forced labor practices only based on official BNP2TKI data, while the massive case that occurs is forced labor on illegal FVC.

Specifically, problems in the network structure of the recruitment scheme and placement of Migrant FVCs are weak regulations to suppress the role of the ship manning agency. Regulations are not yet comprehensive, robust, integrative and are not accompanied by a monitoring and evaluation strategy. Given the ship manning agency is an actor with separate interests from other actors in the network structure. In this case, his party is an agent with a very high economic orientation. The principle of "cost effectiveness" is a big foundation for ship manning agencies in recruiting and placing Migrant FVCs on Taiwan-flagged ships whose needs are increasing every year.

Ahmad Daryoko, a broker operating in the area around Tegal and Pemalang, said that to be able to carry out recruitment procedures, brokers / sponsors must first establish communication with local leaders. This is a basic strategy applied to build trust in community leaders in particular, and prospective migrant workers in general. Thus the chain of recruitment and placement of the Migrant FVC becomes simple "initially I came to the village head, chatted so that there would be no unemployment in his village" (Tempo, 2017). Migrant FVC candidates are then offered to ship management agencies, where if the bidding process is approved, the broker will get a return of 1.5 to 2 million rupiah from the ship manning agency depending on the experience of the Migrant FVC. In the next process, the domestic ship manning agency offers the concerned Migrant FVC to ship manning agencies in Taiwan. All procedures are carried out without involving the government as an actor in the formal and legal structure of recruitment and placement of Migrant FVCs. Recruitment and placement schemes such as those carried out by Ahmad Daryoko and other 
brokers operating in the Tegal and Pemalang areas, of course, thwart various policy and regulatory frameworks that have been established by the Indonesian government in order to eliminate the practice of forced labor that has been going on continuously in the Migrants FVC from year to year. year.

It can be said that the final initiatives taken to address the problem of forced labor are at the national level, generally the reforms carried out by the government to date are still ad hoc and have not developed a coherent and comprehensive strategy in dealing with many central issues regarding migration management in Indonesia. particularly protection of the rights of migrant workers and illegal migration. Although Indonesia has signed the UN Convention on the Protection of the Rights of All Overseas Workers and members of their families concerned, national labor migration laws and policies are still aimed at reducing regional unemployment and tend to focus on facilitating the flow of Indonesian labor migrants rather than creating migrant worker protection mechanisms.

Anderson and Rogaly (2005) identified the factors that cause vulnerability to migrant workers, namely: reliance on recruiters for access to information and access to migration; immigration status; and physical and psychological isolation. In his view, vulnerability in the migration process begins when the state has weaknesses in the law combined with weaknesses in law enforcement resources that cause migrant workers to depend on third parties ${ }^{13}$. This understanding is based on his study of Chinese migrant workers in England (as a placement country) who experience differences in labor practices that have been agreed upon in the work contract with practice in the field after their arrival in England. The manifestation of vulnerability in the recruitment phase for him lies in the different actors causing vulnerability. In the country of origin, the cause of vulnerability is labor recruitment agents. Even if migration is carried out through legal channels, workers will not be immune to forced labor practices carried out by labor users in third parties. This is related to migrant workers' understanding of the laws that protect themselves both in the country of origin and in the country of placement. The work contract runs on "work irregularly to over expenses" and outside the ideal salary to cover “expenses". In the context of Indonesian migrant workers, 'expenditure' can be interpreted as a recruitment fee that is issued by prospective Migrant FVCs during the recruitment process. This fee is allocated for the migrant workers'

13 Rogaly puts the term third parties for employers or labor recruitment agencies and users of labor at the location. placement to migrate 
documents as a condition of being able to go to the country of placement. The causality issue has two propositions in which the recruitment fee is positioned as a condition, and the guarantee fee is the first debt incurred by the prospective migrant worker. At the next level, recruitment fees can be "covered" by deducting workers' salaries which are divided into several salary terms. In this case, third parties or ship manning agencies are the only parties / actors dealing with prospective migrant workers. There is no atmosphere of vulnerability felt by workers because there are no balancing conditions against which migrant workers can measure ideal recruitment conditions.

The second factor, namely immigration status. This status is used by third parties as a medium for abusive actions so that migrant workers cannot escape from the placement country. Action in the relationship between immigration status and the access that migrant workers have is complex (Morris, L. 2004). The implication of the Indonesian fisheries Migrant FVC recruitment scheme is that there is a dichotomy in the status of workers as local crew members and ABK LG or ABK who only have a letter of guarantee, not a work visa. Specific to the employment practices on Taiwanese injured ships, the differences between the two are as follows:

Table 4: Differences in Migrant FVC Status

\begin{tabular}{cll}
\hline No & \multicolumn{1}{c}{ Local } & \multicolumn{1}{c}{ Letter of Guarantee } \\
\hline 1 & $\begin{array}{l}\text { Work on a Taiwan-flagged ship } \\
\text { and sail in Taiwanese waters }\end{array}$ & $\begin{array}{l}\text { Sailing in international waters on a } \\
\text { Taiwan flag ship }\end{array}$ \\
\hline 2 & Legal shipping documents & $\begin{array}{l}\text { Using a visitor visa temporary and } \\
\text { guarantee letter fromrecruiting company } \\
\text { Some leave with illegal shipping } \\
\text { documents }\end{array}$ \\
\hline 3 & $\begin{array}{l}\text { Officially registered as a TKI I I registered with the Ministry } \\
\text { fisheries in Taiwan }\end{array}$ & $\begin{array}{l}\text { Naiwanese Workers. Not recorded at } \\
\text { the Trade Office and the Indonesian }\end{array}$ \\
& & Economy in Taipei \\
\hline 4 & $\begin{array}{l}\text { Salary in Taiwan dollars, } \\
\text { equivalent to about US \$ } \\
600\end{array}$ & $\begin{array}{l}\text { Salary in US \$ 300-400 per month } \\
\text { form of the United States dollar }\end{array}$ \\
\hline
\end{tabular}




\begin{tabular}{ccc}
\hline No & \multicolumn{1}{c}{ Local } & \multicolumn{1}{c}{ Letter of Guarantee } \\
\hline 5 & $\begin{array}{l}\text { Get health insurance } \\
\text { and residence ID cards } \\
\text { foreigners }\end{array}$ & Did not get health insurance \\
\hline
\end{tabular}

Source: Indonesian Slaves on Taiwan Ships, Tempo Institute, $2017^{14}$

Due to their status as illegal workers, sometimes the number of LG crew members is not known with certainty. The data used usually refers to the estimated data carried out by the Indonesian Ministry of Foreign Affairs, where each year there are around 7,000 Indonesian sailors disembarking from Taiwan-flagged ships in Cape Town. Another 5,000 disembarked at two ports in Mauritius, an island in the middle of the Indian Ocean. Lalu Muhammad Iqbal, Director of Protection of Indonesian Citizens and Legal Aid at the Ministry of Foreign Affairs added that "These are just two ports, the total is estimated at over 40 thousand people” (Behind Tempo's Investigation 01, 2017).

In the departure process of the Migrant FVC, what often happens is the mismatch of the placement country agreement with the ongoing placement. The work agreement, generally in writing, states that the worker is placed in Taiwan, but this is not the case in the implementation procedure. As one of the cases advocated by the Environmental Justice Foundation (EJF, 2019), Migrant FVCs are delivered by ship to the place where the ship where the work is leaning, not first through the Taiwan immigration authorities. The ship that is the place to work is currently docked in Palau, so the AKP that departed from Jakarta directly to Palau was not to Taiwan. This situation shows that the AKP does not have a work visa, only a "seaman visa", so that in the future, if there is a problem with the AKP's employer, they cannot enter Taiwan at all to ask the Taiwan government for help. This condition is of course an element of forced labor which leads the AKP to other forms of forced labor because they are limited to access as an option to escape (SR, Jakarta 2020).

The third factor is physical and psychological isolation. Forms of isolation experienced by migrant workers include isolation through language limitations. when dealing with working conditions in the field, one must have good language skills with other workers. The inability to communicate in the language used by

14 This investigation was carried out by TEMPO and independent Taiwanese media to uncover the practices of human trafficking and slavery for tens of thousands of Indonesian crew members aboard Taiwanese fishing vessels operating in open waters. 
co-workers means that migrant workers cannot access basic labor information and information about the basic rights they should get which can be used to gain more control over themselves. In addition, migrant workers will experience another form of isolation, namely isolation from society. This is related to the work environment that does not allow workers to mingle with society which can be used as a medium of seeking help when experiencing or trying to escape from forced labor practices. In the context of Indonesia, the migrant worker union has been pushed through the issuance of the PPMI Law. This is indicated in the third part of CHAPTER II concerning the Rights and Obligations of prospective migrant workers (article 6), where migrant workers have the right to associate and assemble in the destination country of placement. The right to organize is adjusted to the provisions or regulations in force in the country of placement. Likewise with the form of association in the country of origin, as part of the democratic principle Indonesian migrant workers are treated with the same rights to associate and assemble.

The discourse regarding the problem of Migrant FVC and the government's efforts by issuing Law number 18 of 2017 can be understood with the framework of Beckert's market field as an effort to influence the interaction of social forces in the market; enter into the market to contribute to negotiation of issues; and protect the Migrant FVC workers industry as an outcome of the intervention that has been done. In other words, to identify and analyze the relationship on the dynamics of the market that has been built, it can be done if the process of identifying and configuring the constellation of activities, relationships and structures is carried out to improve the quality of the expected transformation. the network structure formed in the market can be a tool for extracting "added value" so that it can become an institution or a policy. This condition simultaneously shows success in the network structure model which has implications for the formation of cultural symbols. This means that the success of a policy depends on cognitive framing for an ideal worker's life.

Until now, the institutional framework which serves as a protection building for the Migrant FVCs in Indonesia cannot be said to be an institution that is responsive enough to the problem of forced labor. The reforms undertaken by the government to date are still ad hoc and have not developed a coherent and comprehensive strategy in dealing with two interrelated matters relating to migration management in Indonesia, particularly the protection of the rights of Indonesian migrant workers and illegal migration. National labor migration policies are still aimed at reducing regional unemployment and 
tend to focus on facilitating the flow of labor migrants rather than creating mechanisms for protecting migrant workers. Even though the PPMI Law has provided a portion for people living in the area of "international ABK pockets" 15 through regulations delegated to local governments such as the implementation of education and job training; Facilitating vocational training for prospective migrant workers; Establishment of integrated services for the placement and protection of migrant workers; and encouragement to associate both in the country of origin and in the country of placement. However, the model built is still partial; there is no special team to be a stakeholder in this idea, because the derivative regulations from the PPMI Law have not been completed; and there is no awareness of association in the Migrant FVC.

Looking at the implementation of recruitment and labor practices involving forced labor experienced by AKP, it can be said that the existing institutions have not been able to transform the AKP's cognitive framework. AKP is employed under ship management agency standards that have been established by the ILO from year to year, this condition indicates that Indonesian Migrant FVC has not been able to establish its identity or recognition of ownership of human rights and labor rights. Owning this identity is a form of legitimacy that is useful to protect him from feelings of powerlessness over the work he does and "personal identity" which positions him among other actors and maps the power relations between himself and other actors which makes him in a dominant position. Incorporating this into Beckert's (2010) idea of "personal identity" which then develops as an identity work is placed into the term cognitive framework which has become part of the aspects of institutional theory and network analysis by combining the two with networks and institutions. The unity of these three social forces is a unique discussion in institutionalist sociology where the emphasis lies on the role of cognitive frameworks and structures as aspects that can explain economic outcomes by expanding the scope of institutions. So that if there is no transformation in the cognitive framework, it means that the institution itself is not interpreted introsubjectively by the object in question (DiMaggio and Powell 1991; Fligstein 2001b: 108; Schneiberg and Clemens 2006; Scott 2008).

Beckert makes three main contributions that can be used to explore the problem of order in the social arena. He sees the market as an entity that is influenced by regulation and law; cultural context; ethics and cooperation; also consumer behavior (Beckert, 1997). And supporting this statement, the

15 Kantung ABK Internasional (bahasa Indonesia) 
market is socially constructed and the conditions can be influenced to achieve an outcome. For Beckert, the market is presented as an entity that is inherently unstable, or can be interpreted as a situation that is difficult to predict the pattern, and actors in the market must face three "problems" to create stability (2007). Stability as a result of the transformation created should be able to form a clear subjective value in the market; realizes advantages through competition from the actors to be protected, when competition is in disequilibrium; and regulating cooperation in the market when problems are difficult to control in terms of quality, reliability or competence. In this process, negotiations between actors will form an order as a way to achieve stability (Beckert 2007).

For Beckert (2010), the agency processes, network structures, institutions and cognitive frameworks in the arena move with the same pattern to produce a transformation. In an ideal form, if the institution succeeds in regulating the network structure, then like the market field scheme, a cognitive framework will be formed that supports each actor to find his own legitimacy so that the ideal cognitive framework in the context of change will be realized.

\section{Conclusion}

Based on the national scale report obtained from the SBMI, the entire service was invalidated because Migrant FVCs cut recruitment and placement procedures through its availability to carry out illegal recruitment procedures. The implementation of policies and regulations basically must touch the cultural aspects of the community in the Migrant FVC enclave. The absence of strong infrastructure support to be able to form a personal identity that is inherent with the work identity as an Migrant FVC. The institution does not show its side of the Migrant FVCs who are illegal due to the impact of illegal recruitment. So that in the country of placement the problem of salary mismatch with work agreements; lack of access to legal protection; freedom of access to personal documents and manpower documents; and association problems ensnare Migrant FVCs. The manifestation can be seen from the awareness of Migrant FVCs to associate; awareness of labor rights and human rights; and dependence only on ship manning agencies without comparison with ideal conditions of legal recruitment and placement carried out on a $G$ to $\mathrm{G}$ basis or in the context of legal migration. 


\section{References}

Anderson, B. \& Rogaly, B. (2005). Forced labour and migration to the UK. London:TUC, Bridgethttps://www.researchgate.net/ publication/253826634

Bales K (2004) Disposable people: New slavery in the global economy. revised edition. Berkeley, CA: University of California Press.

Bernhardt A, Milkman R, Theodore N, Heckathorn D, Auer M, et al. (2009). Broken laws, unprotected workers. New York: Russell Sage Found.

Bravo, K. E. (2007). Exploring the analogy between modern trafficking in humans and the trans-Atlantic slave trade. BU Int'l LJ, 25, 207.

Callon, Michel, 1998: 'Introduction: the embeddedness of economic markets in economics' in The laws of the market. Michel Callon (ed), 1-57. Oxford: Blackwell Publishers. https://doi.org/10.1111/j.1467-954X.1998. tb03468.x

Chapsos, I., \& Hamilton, S. (2019). Illegal Fishing and Fisheries Crime as a Transnational Organized Crime in Indonesia. Trends in Organized Crime, 22(3), 255-273. https://doi.org/10.1007/s12117-018-9329-8

Cresswell, J. W. (2013). Research design: Pendekatan kualitatif, kuantitatif, dan mixed. Yogyakarta. Pustaka Pelajar

Damarsidi, H. R., Susiatiningsih, H., \& Hanura, M. (2017). Analisis anomali kebijakan penempatan TKI: Eksploitasi tenaga kerja Indonesia sebagai anak buah kapal perikanan Taiwan. Journal of International Relations, 3(4), 40-48.

Derks, A. (2010). Migrant Labour and the Politics of Immobilisation: Cambodian Fishermen in Thailand. Asian Journal of Social Sciences. Vol. 38 https://doi.org/10.1163/156853110X530804

Djumadi. (2005). Sejarah keberadaan organisasi buruh di Indonesia. Jakarta: Raja Grafindo Persada.

Doomernik J. 2006. The globalisation, migration and traffificking nexus: European outcomes. See van den Anker \& Doomernik 2006, 20018

Doyle DM, Murphy C, Murphy M, et al. (2018) 'I felt like she owns me': Exploitation and uncertainty in the lives of labour trafficking victims in Ireland. The British Journal of Criminology 59(1): 231-251. 
Gottschalk, P. (2009). Entrepreneurship and organised crime: Entrepreneurs in illegal business. Cheltenham: Edward Elgar Publishing Limited

https://doi.org/10.1111/j.1467-954X.1998.tb03468.x

Kara, S. (2014). Bonded labor: Tackling the system of slavery in South Asia. New York: Columbia Univ. Press

Lyman, M. D. \& Potter, G. W. (2007). Organized crime. New Jersey: Prentice Hall

Marschke, M., \& Vandergeest, P. (2016). Slavery scandals: Unpacking labour challenges and policy responses within the off-shore fisheries sector. Marine Policy, 68, 39-46. doi:10.1016/j.marpol.2016.02.009

Nugroho, H. \& Tjandraningsih, I. (2007). Fleksibilitas pasar kerja dan tanggungjawab negara, kertas posisi, terbit terbatas

Patterson, O., \& Zhuo, X. (2018). Modern trafficking, slavery, and other forms of servitude. Annual Review of Sociology, 44(1), 407-439. doi:10.1146/ annurev-soc-073117-041147

Phillips, C. (2020;2019;). Utilising 'modern slave' narratives in social policy research. CriticalSocial Policy, 40(1),30-49.doi:10.1177/0261018319837217

Tony, J. W.( 2003). Sociology, work and industry. New York: Routledge

Watson, T. J. (2009). Work and the sociological imagination: The need for continuity and change in the study of continuity and change. Sociology, 43(5), 861-877. doi:10.1177/0038038509340726

Coventry University, Kementerian Kelautan dan Perikanan RI, IOM. 2016. Report on Human Trafficking, forced labour and Fishers Crime in The Indonesian Fishing Industry.

Environmental Justice Foundation (EJF). 2018. Human trafficking in Taiwan's fisheries sector. Jakarta

International Labour Organization. (2013). Caught at Sea: forced labour and Trafficking in Fisheries. Geneva: International Labour Organization. Link B, Phelan J. 1995. Social conditions as fundamental causes of disease. J. Health Soc. Behav. 35:80-94

Investigasi Tempo, Budak Indonesia di Kapal Taiwan. 2017 Liputan Kerja Sama Tempo, Tempo Institute, Dan Free Press Unlimited.

ILO FUNDAMENTALS. 2018. Measurement of forced labour. Geneva

Robertson, P. (2011). Trafficking of fisherman in Thailand. International Organization for Migration. Bangkok, Thailand. 
MOP (2012), Migration in Cambodia: Report of the Cambodian Rural Urban Migration Project, Ministry of Planning, Phnom Penh.

https://koran.tempo.co/read/laporan-utama/411117/perbudakan-abkindonesia-terjadi-di-banyak-negara? read $=$ true

www.Taiwan.gov.tw, n.d diakses pada 1 Mei 2020

https://maritim.go.id/menko-luhut-tegaskan-pentingnya-peningkatan-standarpendidikan-pelatihan/ diakses pada 5 April 2020

https://www.ilo.org/jakarta/info/WCMS_124563/lang-en/index.htm. Diakses pada 2 Februari 2019

https://jateng.tribunnews.com/2016/05/25/fakta-mengejutkan-lebih-dari300-abk-dibunuh-dan-jenazahnya-dibuang-kelaut-asuransi-ditilep

https://batam.tribunnews.com/2016/08/19/nasib-tragis-supriyanto-nelayantegal-yang-jadi-budak-kapal-ikan-taiwan-disiksa-hingga-tewas?page $=4$

\section{(Footnotes)}

1 Note: In the concept used by the Ministry of Manpower, AKP LG is an AKP that sails outside the territory of Taiwan 